\title{
2. 結晶構造からみた物性予測と反応予測
}

\section{有機顔料の結晶多形と電子構造}

\author{
横浜国立大学大学院工学研究院 水口 仁
}

\section{Jin MIZUGUCHI: Correlation between Crystal and Electronic Structures in Organic Pigments}

Correlation between crystal and electronic structures in dithioketopyrrolpyrrole pigment (DTPP) has been reviewed on the basis of the molecular exciton theory as well as on the polarized reflection measurements on single crystals. The mechanism of the near-IR absorption of DTPP has been clarified as arising from the molecular arrangement of "bricks in a brick wall" structure as characterized by J-aggregates in cyanine dyestuffs.

\section{1. はじめに}

分子には色々な種類の異性体が存在し, その中でも光学 異性体は 2 つの分子の構造が極めて類似し鏡像体の関係 にあるものである．しかし，互いに鏡像の関係にある分子 であっても各々の性質が大きく異なることがある.例えば 光学異性体の一方は医薬に有効であっても，もう一方はサ リドマイドにみられるように薬害となることがある. 2001 年のノーベル化学賞を受賞された名古屋大学の野依良治 教授の業績は光学異性体の一方のみを取り出す不斉合成 の先駆的な研究である.

結晶多形の問題もこれに類似した点がある.いくつか の結晶変態の中で，ある1つの結晶相のみが半導体レー ザーの発振波長である近赤外領域に吸収帯を有するとか， あるいは際立って高い光伝導性を示す例である. また, 有 機顔料の分野では, 同じ顔料でもある特定の結晶相の色 調のみが好まれることがある. 有機顔料では結晶多形の 存在が粉末 X 線などの解析で確認されているが, 単結晶 の形で単離されて結晶構造と電子構造の相関関係が検討 されている例は極めて少ない.1)本稿では 3 つの結晶多形 が存在するジチオケトピロロピロールを例として有機固 体の結晶構造と電子構造の相関関係を議論したい. ジチ オケトピロロピロールは半導体レーザーの発振波長であ る近赤外領域に吸収帯を有し，レーザープリンターの感 光体や光ディスクの記録媒体として注目を集めている青 色顔料である.21.31

\section{2. ジチオケトピロロピロールと分子間相互作用}

分子の電子遷移は一般に分子内の電子共役が大きい程 (大雑把に言って分子量が大きい程) 長波長側に出現する. 図 1 (a) の抻絵に示すジチオケトピロロピロール (DTPP) は分子量がわずか 320 の分子であるが, 固体状態では近赤 外部に吸収带を有する.4) 同様な近赤外吸収を示すチ夕二
ルフタロシアニン (TiOPc：図 1 (b) ) がDTPP の約 2 倍の 分子量をもつことを考えると DTPP分子の近赤外吸収は 実に驚くべきことである.このような効果は分子間の相互 作用のなせる業である。 また, TiOPc の溶液スペクトルは シャープな1本の吸収バンドであるが, 固体状態では驚く べきほど広い波長範囲で吸収を示すようになる。これも分 子配列に依存する分子間の相互作用の結果である.5

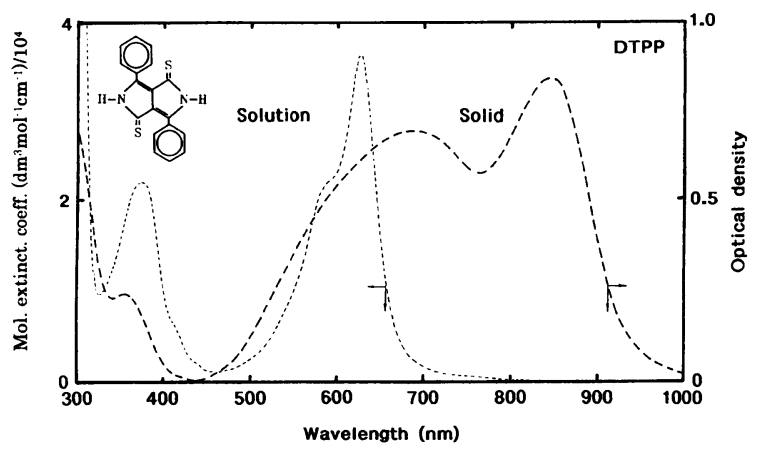

(a)

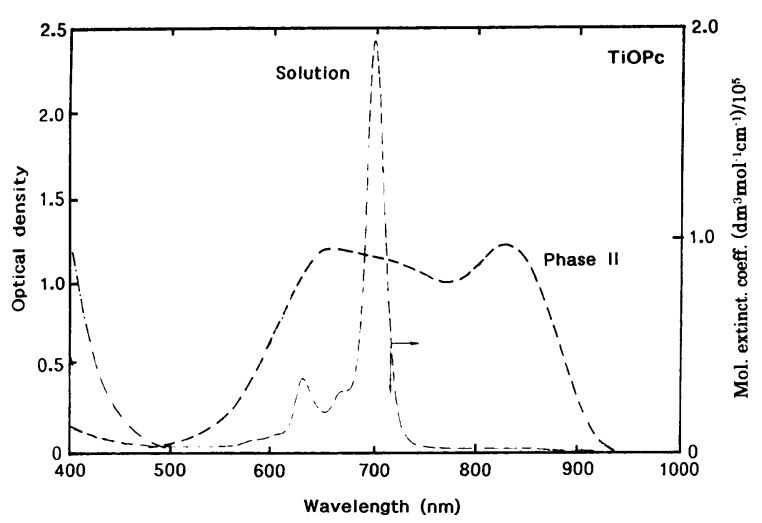

(b)

図1 溶液スペクトルと蒸着膜スペクトル: (a) DTPP (b) TiOPc. (Solution and solid-state spectra in evaporated films : (a) DTPP and (b) TiOPc.)

日本結晶学会誌第 44 巻 第 1 号 (2002) 


\section{3. 有機固体の電子構造 \\ 一基底状態ならびに励起状態における}

\section{分子間相互作用一}

分子の集合体を考えるとき，分子間相互作用が大きい とか小さいということが多い. 分子間相互作用を議論す る際には基底状態における分子間相互作用であるのか, あ るいは励起状態における相互作用 (励起分子間の相互作用) であるのかを明瞭に区別する必要がある.

基底状態にある分子の分子間相互作用は結晶構造と密 接に関係している. 分子間相互作用が強いということは 分子間に強固な力が作用していることを意味し，物質が 硬いとか, 溶剤に不溶であるとか, さらには熱・光に対し て極めて安定であるといった物性に対応している。

これに対して, 励起状態の相互作用とは励起分子間の相 互作用であって, 物質の色調, 光伝導, 蛍光現象に深くか かわっている. 一般に励起分子間の相互作用は遷移モーメ ント間の相互作用として記述され, 分子配列は遷移モーメ ントの 3 次元的な配置を決めている.さらに重要なこと は物質の吸収係数が遷移モーメントの 2 乗に比例する量

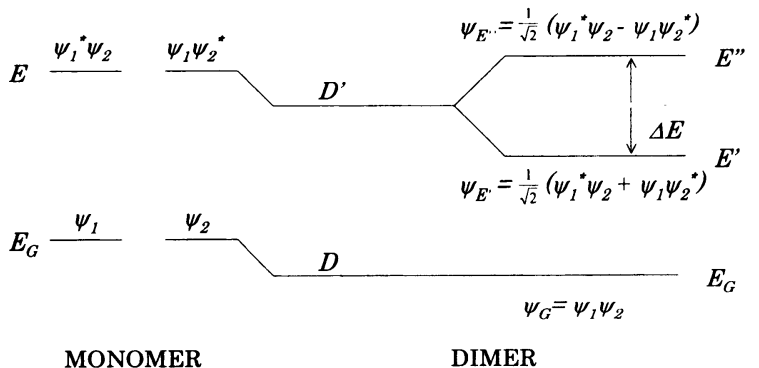

図2 単量体と二量体の電子スペクトル準位. (Energy diagram for molecular excitions in dimers.)

(a)
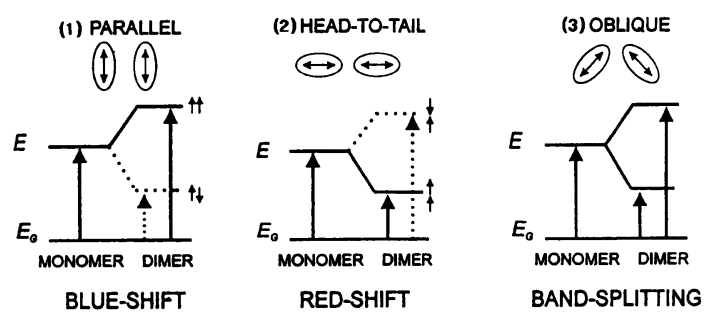

(b)
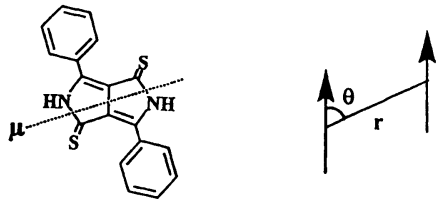

図3（a）遷移モーメント間の相互作用とスペクトルシフ ト（b）DTPPの遷移モーメント. ( (a) Interactions between transition dipoles and resulting spectral shifts and (b) direction of the transition dipole of DTPP.)
であることから，モル吸光係数 (単位： $\mathrm{dm}^{3} \mathrm{~mol}^{-1} \mathrm{~cm}^{-1}$ ) が 10000 を優に越えるような色素や顔料では励起分子間の 相互作用が非常に大きくなる. その結果, 分子の励起状態 は共鳴相互作用により結晶中を伝播し非局在化する.これ を励起子状態 (exciton state) と呼ぶ.ここで注意すべきこ とは励起分子間の相互作用には分子間の結合 (bond) が必 ずしも強固である必要はないことである. 分子間力が弱く ても, (吸収係数が大きい場合には) 分子が単に規則正しく 並んでいれば励起分子間の相互作用は出現する.しかし, 基底状態の相互作用は分子の配列 (結晶構造) を決め, 一 方励起状態の相互作用は分子の 3 次元的な配列に依存す る効果であるから, 両者の相互作用は分子座標を通して密 接に関係していることになる.つまり, 励起分子間の相互 作用は基底状態の相互作用により決まった分子の 3 次元 的な座標の上で展開される.

以上の相互作用を念頭におき，孤立した状態にある分 子 (単量体) から集合体 (ここでは二量体)へと移行する過 程を考えてみよう.6) 通常, 有機物の吸収スペクトルは結 晶化に際して長波長化することが多い. 単量体の2つの 分子の波動関数を $\psi_{l}, \psi_{2}$ のように書き, 励起状態を $\psi_{l}{ }^{*}$, $\psi_{2} *$ のように“*”を付けて記すと, 二量体の励起状態に は< $\psi_{1}^{*} \psi_{2}|V| \psi_{1} \psi_{2} *>$ のような相互作用が出現する.ここ にVはクーロン相互作用のハミルトニアンである. 二量 体の基底状態はファンデアワールス相互作用 $\left(<\psi_{1} \psi_{2}|V|\right.$ $\left.\psi_{1} \psi_{2}>\right)$ により安定化する $(D)$. 同様に励起状態にある 分子と基底状態にある分子からなるぺアの間にも安定化 $\left(<\psi_{1}^{*} \psi_{2}|V| \psi_{1}^{*} \psi_{2}>\right)$ が起こる $\left(D^{\prime}\right)$. この差 $\Delta D=D^{\prime}-D$ はクリスタルシフト (crystal shift) と呼ばれる。これに遷 移モ一メント間の相互作用 $\Delta E_{\text {exciton }}\left(\left\langle\psi_{1} * \psi_{2}|V| \psi_{1} \psi_{2} *\right\rangle\right)$ が加わる. 以上の結果をまとめると分子が溶液から固体に 移行する際の二量体の遷移エネルギー $(E)$ は以下の式で 表される.

$$
E_{\text {dimer }}=E_{\text {monomer }}+\Delta D \pm \Delta E_{\text {exciton }}
$$

遷移モーメント間の相互作用 $\left(\Delta E_{\text {exciton }}\right)$ は Kasha, ${ }^{6)}$ Craig \& Walmsley7)らにより詳細に検討された. 理論の概略と DTPPの遷移モーメントの方向4)を図3に示す。遷移モー メントが平行の場合 (並進等価)には相互作用エネルギー $(\Delta E)$ は次式で記述される： $\Delta E=|\mu|^{2}\left(1-3 \cos ^{2} \theta\right) / r^{3}$, ここ で， $\mu$ は遷移モーメント， $\theta$ は遷移モーメント間のなす角 度, $r$ は遷移モーメント間の距離である。この式からわか るように, $\theta$ が $54.7^{\circ}$ より大きい時にはブルーシフト（短 波長シフト) となる(図3(a)（1))。これに対し， $\theta$ が54.7 より小さい時には励起準位は低エネルギー側にシフトし, 光学遷移はレッドシフト (長波長シフト) となる (図3 (a) (2)). 図 3 (a)（1）ならびに図 3 (a)（2）で遷移モーメント がお互いに向き合うような配置では遷移モーメントが相 殺されて禁制遷移となる。また，2つの遷移モーメントが 平行ではない場合 (並進非等価)にはべクトルの和と差に

日本結晶学会誌第 44 卷 第 1 号 (2002) 


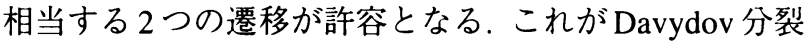
である(図3(a) (3)).

上記のように遷移モーメントが平行な場合には一方の 遷移が禁制となるのでスペクトルシフトしか起こらない. したがって，結晶化に伴う実験的なスペクトルシフトが クリスタルシフトの効果によるものか，あるいは励起子 相互作用に基づく効果であるかの判定は難しい. しかし， 並進非等価な分子配列 (図 3 (a) (3)) が存在する結晶であ ればDavydov 分裂を（偏光反射スペクトルなどで）実験的 に示せるので, 励起子状態 (exciton state) の存在を実証す ることができる.そしてこれを根拠に並進等価な分子配 列においても遷移モーメント間の相互作用の寄与がある と主張することが可能である.

\section{4. ジチオケトピロロピロールの結晶多形}

気相から育成した 3 種類の単結晶の結晶学的パラメー ターを表 1 に示す.8), 9) 図 4 に結晶変態 I, II の杉綾模様 (herringbone) と結晶変態 III の“レンガ塀のレンガ” (bricks in a brick wall) 構造の模式図を示す. 3 つの結晶変態はす

表 1 結晶変態 I, II, III の結晶パラメーターと分子配列。 (Crystallographic data and molecular arrangement of modifications I, II and III.)

\begin{tabular}{|c|c|c|c|}
\hline & 結晶変態I & 結晶変態II & 結晶変態III \\
\hline 分子の対称性 & $C_{\mathrm{i}}$ & $C_{\mathrm{i}}$ & $C_{2}$ \\
\hline$Z$ & 2 & 2 & 4 \\
\hline 空間群 & $P 2_{1} / n$ & $P 2_{1} / n$ & $C 2 / c$ \\
\hline$a(\AA)$ & $7.986(1)$ & $4.873(1)$ & $27.008(4)$ \\
\hline$b(\AA)$ & $4.757(1)$ & $18.613(2)$ & $6.982(1)$ \\
\hline$c(\AA)$ & $19.685(3)$ & $7.995(1)$ & $7.935(1)$ \\
\hline$\beta\left(^{\circ}\right)$ & $99.18(2)$ & $95.76(2)$ & $100.64(1)$ \\
\hline$V\left(\AA^{3}\right)$ & $738.2(5)$ & $721.5(5)$ & $1470.6(7)$ \\
\hline $\begin{array}{l}\text { フェニル環 } \\
\text { のねじれ裙) }\end{array}$ & $\begin{array}{l}\text { 13.3(5) } \\
\text { 同方向 }\end{array}$ & $\begin{array}{l}6(1) \\
\text { 同方向 }\end{array}$ & $\begin{array}{l}30.1(2) \\
\text { 逆方向 }\end{array}$ \\
\hline 複素環の2面角 $\left({ }^{\circ}\right)$ & 180 & 180 & $174.6(1)$ \\
\hline 分子の積層構造 & 杉綾模様 & 杉綾模様 & レンガ塀のレンガ \\
\hline $\begin{array}{c}\text { 双極子モモーメント } \\
\text { (Debye)* }\end{array}$ & 0.015 & 0.000 & 0.273 \\
\hline
\end{tabular}
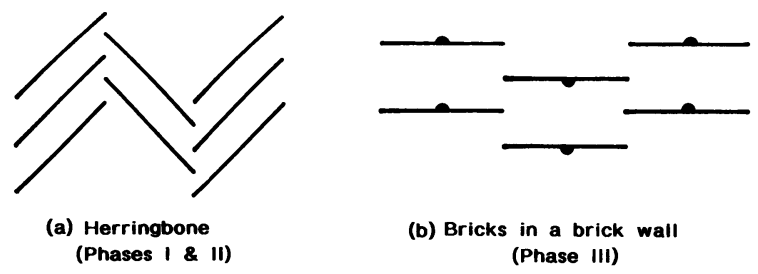

図4 DTPPの分子配列：(a) 杉綾模様 (b) レンガ塀レン ガ. (Molecular arrangement of DTPP : (a) herringbone and (b) bricks in a brick wall.)
べて単斜晶系に属する．結晶相ＩとＩI は非常に類似し，分 子の対称性はともにCi で双極子モーメントをもたない.4) また, 複素環の 2 面角は $180^{\circ}$ で, 2 つの 5 員環の作る縮合 環 (heterocyclic ring system) は平面をなす。この面に結合 するフェニル環も結晶相 I，II でそれぞれ $13^{\circ}, 6^{\circ}$ ずつ同 方向にねじれている。これに対し, 結晶変態 IIIでは結晶化 の際に分子の対称性が $C_{\mathrm{i}}$ から $C_{2}$ に変化し, 約 0.3 デバイ の双極子モーメントが出現する.4)このため, 分子はシア 二ン色素の J 一会合体 10) と極めて類似した“レンガ塀の レンガ” (bricks in a brick wall) の積層構造をとる（図4 (b)). 複素環の 2 面角も $175^{\circ}$ で, 複素環の中央でわずかに 折れ曲がっているのが特徴である.さらに，フェニル環の ねじれ方向もお互いに逆方向で, いわゆるプロペラ型の構 造をとっている.

図 $5(\mathrm{a})$ は結晶変態 $\mathrm{I}$ の構造 ${ }^{8)}(a, c)$ 面上に投影した もので, $a$ 軸方向に NH $\cdots \mathrm{S}$ に基づく分子間水素結合が認 められる.しかし，2つの分子面にはわずかな段差（約 0.7 Å) が存在する. また，すべての分子は $(a, c)$ 面上で同方 向に整列している. 図5 (b) は $(b, c)$ 面上への投影図で, 分 子は杉綾模様 (herringbone) の積層構造をとっている (図4 (a)）. 分子の両端では分子は隣接分子とほぼ直角に交差す る.この位置には, フェニル環のパラ位置の水素原子と, もう一方の分子のフェニル環 $(\boldsymbol{\pi}$ 電子面）との間に $\pi$ 型水 素結合が存在する.

結晶変態 II の構造8)を図6に示す. 結晶変態 II はI とほ ほ同じ構造をとるが，図5(a)のように全分子が同方向に 配列せず, $b$ 軸に沿ってジグザグな構造をとる (図6 (a)).

図7 (a) は結晶構造 III') を $(a, c)$ 面に投影したものであ
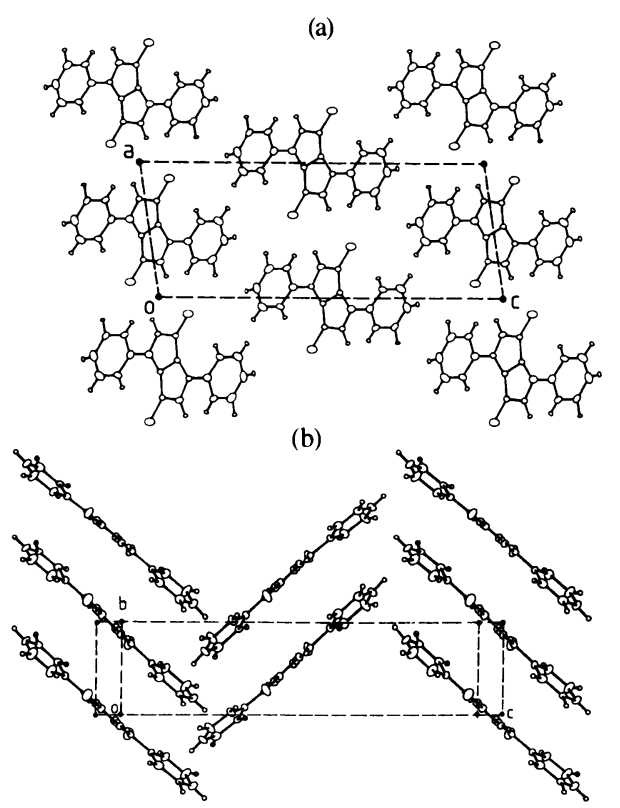

図 5 結晶構造 I：(a) $(a, c)$ 面への投影図 $(\mathrm{b})(b, c)$ 面 への投影図. (Projection of structure I: (a) onto the $(a, c)$ plane and (b) onto the $(b, c)$ plane.)

日本結晶学会誌 第 44 巻 第 1 号 (2002) 
る. 黒点を付けた分子は同一面上にあり, 黒点の付いてい ない分子は一格子面だけ下に位置する．各々の格子面で 分子は水素結合により 2 次元的に結合し，すべての分子は 完全に分子面上にある. 3 つ分子の重なり状態を示した のが図7 (b) である. 分子 $\mathrm{C}$ は分子 $\mathrm{A}$ の真下に位置し, 2 倍 の面間隔で隔たっている. 分子 $\mathrm{B}$ は分子 $\mathrm{A}, \mathrm{C}$ の間に挿入 され，一見すると分子間にまったく重なりがないように
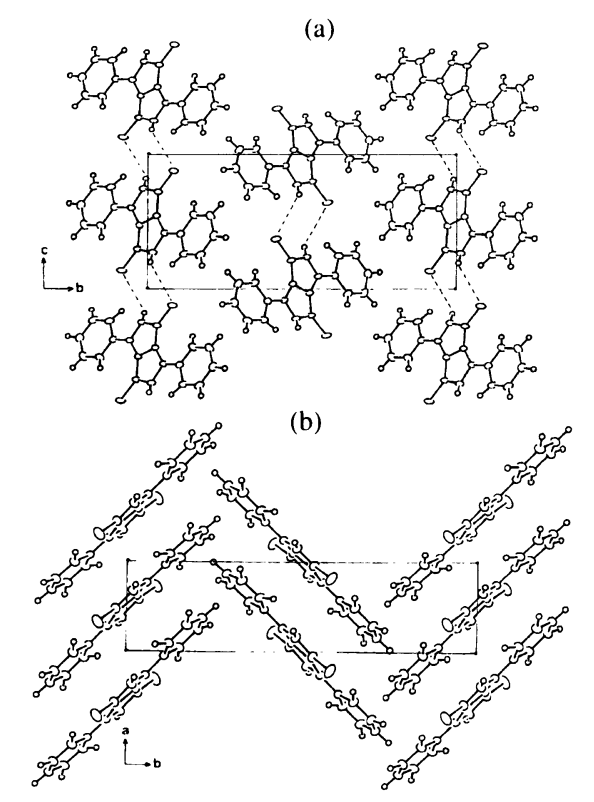

図6 結晶構造 II：(a) $(b, c)$ 面への投影図 $(\mathrm{b})(a, b)$ 面 への投影図. (Projection of structure II : (a) onto the $(b, c)$ plane and $(\mathrm{b})$ onto the $(a, b)$ plane. $)$
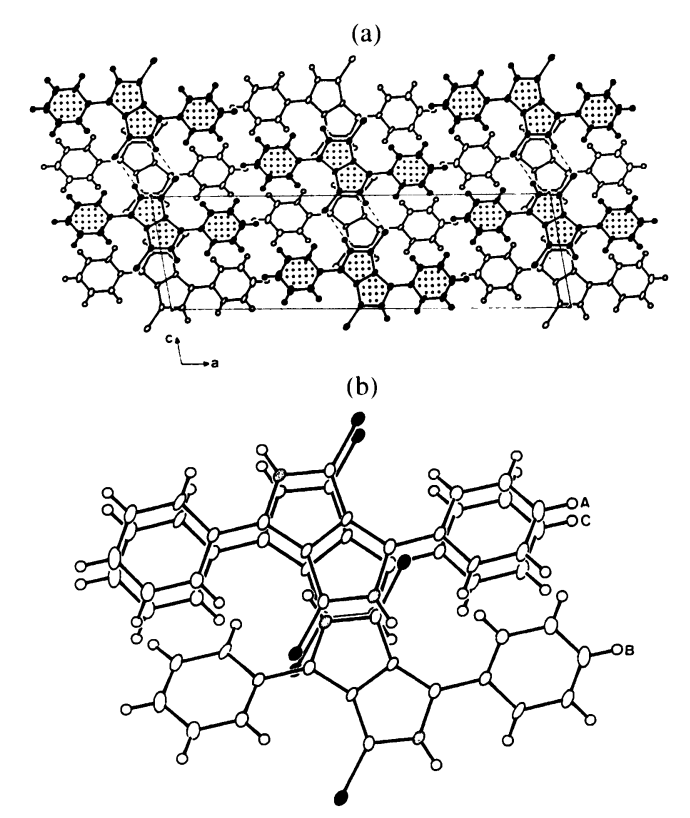

図 7 結晶構造 III：(a) $(a, c)$ 面への投影図 (b) 積層方 向の 3 分子の重なり. (Crystal structure of modification III : (a) projection onto the $(a, c)$ plane and (b) overlap of three molecules along the stacking $b$-axis.)
みえる.しかし, 注意深く観察すると分子 $\mathrm{A}$ の窒素原子の 真下には分子 B のチオ・カルボニル基の炭素原子が存在 し，また分子 $\mathrm{A}$ のオ・カルボニル基の真下にも分子 $\mathrm{B}$ の窒素原子がある.つまり, 積層方向に沿って分子の両側 で炭素／窒素の繰り返しによる4つの柱 (column) が存在 し，この方向に大きな $\pi$ - $\pi$ 相互作用があることがわかる. この $(a, c)$ 面への投影図を $a$ 軸方向から観察すると“レン ガ塀のレンガ” (bricks in a brick wall) の構造 (図 4(b)) をとっていることがわかる.

ここで注目したいのは分子 $\mathrm{A}$ は分子 $\mathrm{C}$ に並進操作で移 すことができるが，分子 $\mathrm{A}$ は分子 Bに移すことはできな いということである.すなわち, 結晶変態IIIには $2 つ の$ 配座 (conformation) が存在し, 分子 A (C) は分子 B と対掌 体 (enatiomorph) をなすことである. 2 種類の配座は結晶 内で以下に述べる 2 種類の分子対を組んでいる. 複素環の
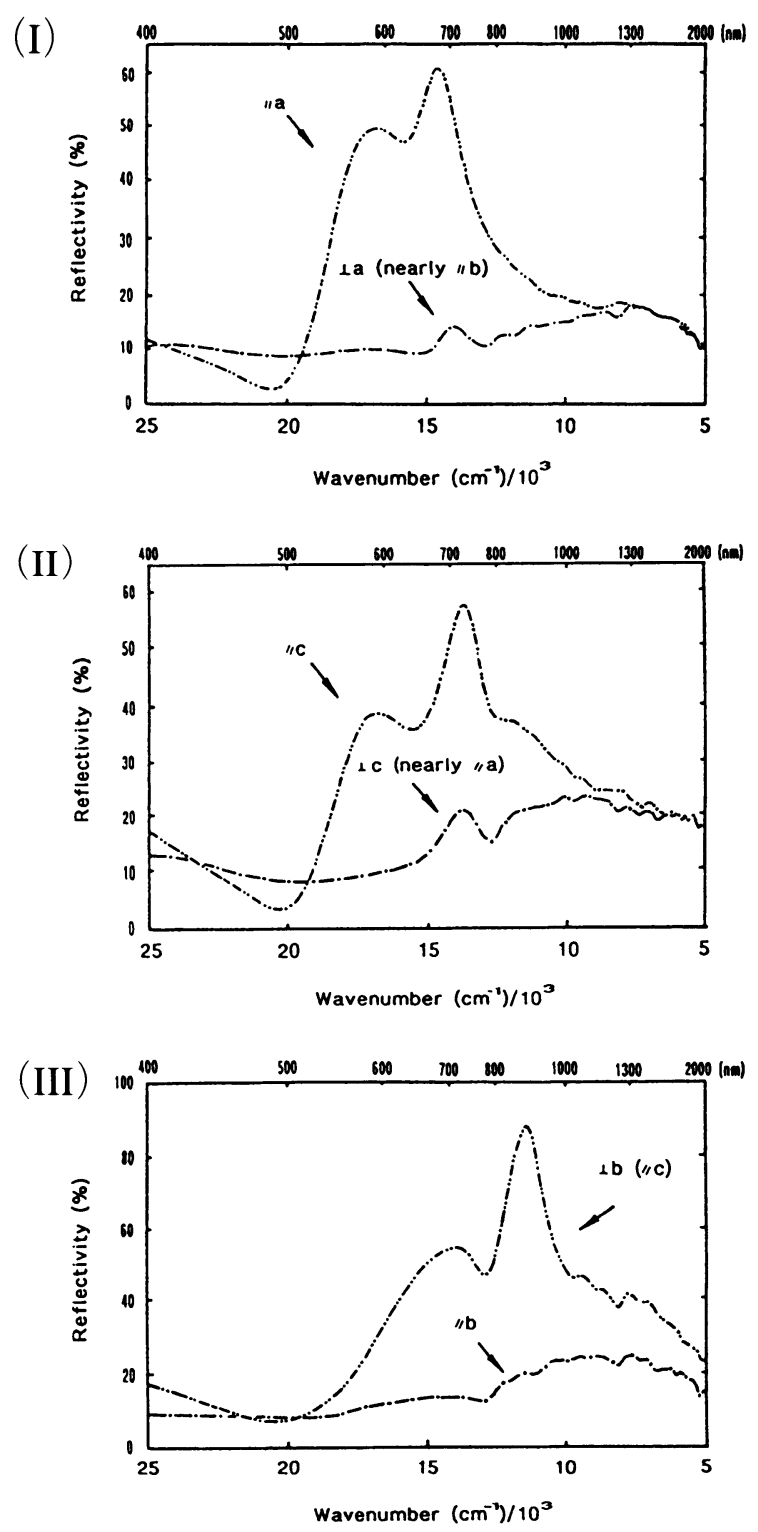

図8 結晶変態 I, II, III の偏光反射スペクトル. (Polarized reflection spectra for modifications I, II and III.) 
中央で折れ曲がったピロロピロール骨格 (2面角：175º) をお椀のように考えるとお椀の背中と背中を組み合わせ た convex ペア (分子対 $\mathrm{AB}$ ) (図 7 (b) ) と腹と腹を組み合わ せた concaveペア (分子対 BC) が存在する. Convex ペアで はA 分子の “N”原子と B 分子の “C”原子(チオカルボ二 ル炭素) との距離は $3.496 \AA$ で, concave ペアの $3.518 \AA$ に比べて短い.8).91

\section{5. 単結晶の偏光反射スペクトル}

顕微分光装置は顕微鏡の光学系を使い単結晶の偏光反 射スペクトルを測定する装置である.11) 図8に結晶相 I, II, III のそれぞれ (001), (010), (100) 面で測定した単結晶 の偏光反射スペクトルを示す.4)

結晶相 I と II は構造が類似していることを反映して, 両 者は非常に似通った反射スペクトルを示す，それぞれ $a$ 軸 と $c$ 軸に平行な偏光で励起すると強い反射が得られるの に対し, $a$ 軸と $c$ 軸に垂直 (分子の積層方向) な偏光では反 射が消滅し，710－720 nm にさな極大がみられるのみ である.これは積層方向のわずかな電荷移動遷移である.

結晶相 III では $c$ 軸に平行な偏光 (分子間の水素結合の 方向)では $850 \mathrm{~nm}$ 近傍に大きな反射極大が存在する。こ の反射バンドは結晶相 I, II に比べ約 $150 \mathrm{~nm}$ 長波長側にシ フトしている. また，励起光の偏光方向が図 $3(b)$ に示す 遷移モーメントの方向であることから, DTPPの遷移モ一 メントは水素結合に沿った方向であることがわかる

以上の反射スペクトルの結果より，分子の配列が異な ると反射スペクトルが大きく異なることがわかる．結晶 相 III の近赤外部の反射バンドには遷移モーメント間の相 互作用が関与していることを以下に示す。

\section{6. 遷移モーメント間の相互作用とスペクトルシフト}

3.で述べたクリスタルシフトや励起子相互作用を解析的 に計算することは現時点では至難の業である。ここでは遷 移モーメント間の相互作用を実験データから概算し, 分子 の空間座標 (分子配列) と吸収带との相関関係をみてみよう。

表 2 は双極子一双極子相互作用の式 $(\Delta E=|\mu| 2(1-$ $\left.\left.3 \cos ^{2} \theta\right) / r^{3}\right)$ を用いて計算した最近接分子に対するスペク トルシフトである.12) 表 2 には結晶構造から直読した遷移 モーメント間の角度 $(\theta)$ と距離 $(r)$, 分数座標 (fractional coordinate) で表示した分子の位置（site）並びに等価な分子 の数も示してある. 遷移モーメント $(\mu)$ の計算はX 線座標 を使って INDO/S 計算から算出した，負の数值は励起準 位の低エネルギー側へのシフト（長波長化）を示し，正の 数值は高エネルギー側へのシフト (短波長化) に対応する。 また，結晶変態 III の積層ペアは convex ペアと concave ペ アの平均值を示す.

図4の模式図を参照しながら表 2 の計算結果を検討し てみてみると, 結晶相 I および II では水素結合ぺア $(\mathrm{H}-$ bond pair ; “head-to-tail”配置) は励起エネルギー準位を約 $1500 \mathrm{~cm}^{-1}$ 低エネルギー側へシフトさせていることがわか る.さらに, 杉綾模様の積層構造では約 $1800 \sim 2500 \mathrm{~cm}^{-1}$ 程度の短波長シフトを誘起している. スペクトルシフトに 加成性がなり立つと仮定して，12 個の最近接分子に対す

表 2 (a) 結晶相Iにおける12 最近接分子とシフトエネル ギー.(12 Nearest neighbors around the molecule at $(1 / 2,0,0)$ and their displacement energies in modification I.)

\begin{tabular}{lccccc}
\hline \multicolumn{1}{c}{ Type of molecule pairs } & $\begin{array}{c}\text { Number of } \\
\text { molecules }\end{array}$ & Site & $\begin{array}{c}r \\
(\AA)\end{array}$ & $\begin{array}{c}\theta \\
\left({ }^{\circ}\right)\end{array}$ & $\begin{array}{c}\Delta E^{*} \\
\left(\mathrm{~cm}^{-1}\right)\end{array}$ \\
\hline H-bond pairs along the $a$-axis & 2 & $(3 / 2,0,0)$ & 7.9 & 6.0 & -1486 \\
Stack pairs along the $b$-axis & 2 & $(1 / 2,1,0)$ & 4.8 & 66.0 & 1761 \\
Diagonal pairs along the $c$-axis & 2 & $(0,1 / 2,1 / 2)$ & 10.3 & 75.4 & 280 \\
& 2 & $(1,1 / 2,1 / 2)$ & 10.3 & 75.4 & 280 \\
& 2 & $(0,-1 / 2,1 / 2)$ & 10.3 & 75.4 & 280 \\
& 2 & $(1,-1 / 2,1 / 2)$ & 10.3 & 75.4 & 280 \\
\hline & 12 & & $\Delta E\left(\mathrm{~cm}^{-1}\right)$ in total $=2790$ \\
& & & & &
\end{tabular}

表 2 (b) 結晶相II における 12 最近接分子とシフトエネル ギー.(12 Nearest neighbors around the molecule at $(1 / 2,0,1 / 2)$ and their displacement energies in modification II.)

\begin{tabular}{lcccccc}
\hline \multicolumn{1}{c}{ Type of molecule pairs } & $\begin{array}{c}\text { Number of } \\
\text { molecules }\end{array}$ & Site & $\begin{array}{c}r \\
(\AA)\end{array}$ & $\begin{array}{c}\theta \\
\left({ }^{\circ}\right)\end{array}$ & $\begin{array}{c}\Delta E^{*} \\
\left(\mathrm{~cm}^{-1}\right)\end{array}$ \\
\hline H-bond pairs along the $(-$-axis & 2 & $1 / 2,0,3 / 2$ & 8.0 & 7.5 & -1575 \\
Stack pairs along the $a$-axis & 2 & $(3 / 2,0,1 / 2$ & 4.9 & 72.0 & 2543 \\
Diagonal pairs along the $b$-axis & 2 & $(0,1 / 2,0)$ & 10.51 & 66.2 & 181 \\
& 2 & $(0,1 / 2,1)$ & 10.51 & 66.2 & 181 \\
& 2 & $(1,1 / 2,0)$ & 10.51 & 66.2 & 181 \\
& 2 & $(1,1 / 2,1)$ & 10.51 & 66,2 & 181 \\
\hline & 12 & & \multicolumn{4}{c}{$\Delta E\left(\mathrm{~cm}^{-1}\right)$ in total $=3384$} \\
$*$ & & & &
\end{tabular}

表 2 (c) 結晶相III における16最近接分子とシフトエネル ギー. (16 Nearest neighbors around the molecule at $(0,3 / 4,1 / 4)$ and their displacement energies in modification III.)

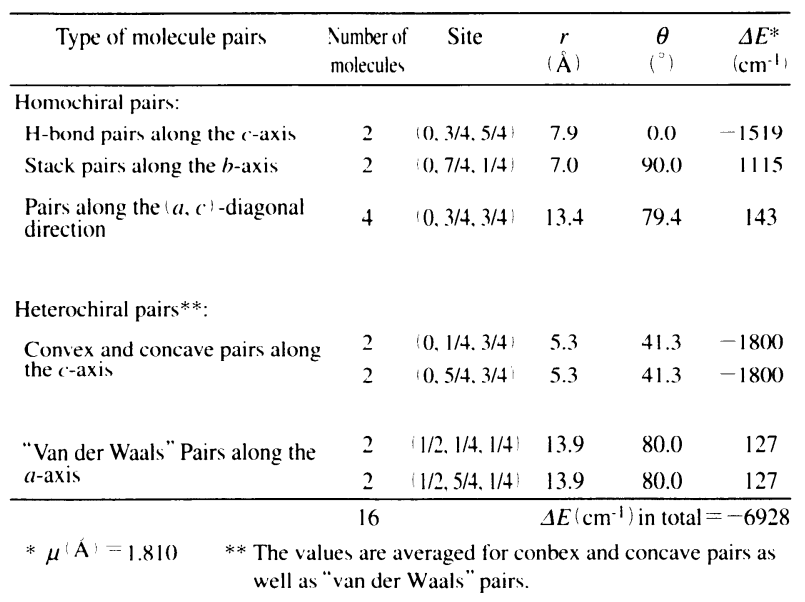

日本結晶学会誌第 44 卷 第 1 号 (2002) 
るスペクトルシフトの総和をとると 2800 ～ $3400 \mathrm{~cm}^{-1}$ の 短波長シフトとなる。

結晶相III の構造と計算結果を詳しくみてみよう。結晶 構造 III には3つの特徵的な分子ペアが認められる. 第 1 番目は $c$ 軸方向に沿った分子間の水素結合のペア (H-bond pair ; homochiral pair (同じ旋光性を示す分子対)) で2つ の分子は “head-to-tail” の配置をとる. また, $b$ 軸方向の “parallel”な構造をとる積層ペア (stack pair; homochiral pair) もある (分子ペア $\mathrm{AC}$ ). さらに, 積層方向にはやや斜目に 位置するペア (分子対 $\mathrm{AB}$ 並びに分子対 $\mathrm{BC}$; heterochiral pair (逆回転の旋光性を示す分子対)）もある. 結晶相 I およ びIIの結果と同様に水素結合ペアは約 $1500 \mathrm{~cm}^{-1}$ 程度, 励 起エネルギー準位を低エネルギー側ヘシフトさせている. さらに, 斜め方向の積層ペアである分子ペア $\mathrm{AB}$ および $\mathrm{BC}$ (convex pair \& concave pair) も約 $1800 \mathrm{~cm}^{-1}$ 長波長シ フトに寄与し, このような分子ペアが 2 個ずつ存在するこ とは大きなレッドシフトの原因となる。この分子ペアは “レンガ塀のレンガ”構造の特徴である. これに対し, 励起 エネルギー準位を高エネルギー側へシフトさせる分子ペ アは $b$ 軸に沿った積層ペア (homochiral stack-pair)のみ で，その大きさは $1100 \mathrm{~cm}^{-1}$ 程度である. スペクトルシフ トの総和は約 $7000 \mathrm{~cm}^{-1}$ の長波長である.

以上のように遷移モーメント間の相互作用の計算結果 をみると結晶相 I およびIIでは約 2800 ～ $3400 \mathrm{~cm}^{-1}$ 短波 長化し, 結晶相 III では逆に約 $7000 \mathrm{~cm}^{-1}$ 長波長化に奇与し ていることがわかる。この長波長化の効果の主因は積層方 向の対角ペアに基づくものである。, 一方, 結晶化に伴う長 波長化の実験值は結晶相 I おうよび II では約 $1500 ２ 400$ $\mathrm{cm}^{-1}$, 結晶相 III では約 $4200 \mathrm{~cm}^{-1}$ である.この結果から, 結 晶相 I およびIIではクリスタルシフトの長波長化の効果 が遷移モーメント間の相互作用の短波長効果を上回って いることが示唆される.また, 結晶相III では遷移モーメン 卜間の相互作用に起因する長波長化の効果が大きく, クリ スタルシフトの長波長化の効果とで大きな長波長シフト を誘起していると考えられる.ささらに, 結晶相I, II, III で は, 水素結合の効果が共通であることから長波長化(近赤 外吸収)を決めているのは積層方向の “レンガ塀のレンガ” 構造であることが結論される。

\section{7. 分子間水素結合の役割}

本稿で取りあげたピロロピロールは分子間水素結合を 形成した有機顔料の典型であるが, 同種の顔料としてイン ジゴやキナクリドンが知られている.これらの顔料では分 子間の水素結合が極めて重要で2つの役割を担っている ことがわかる。まず, 分子間水素結合は遷移モーメントを “head-to-tail”配置にそろえ, 大きな長波長シフトを誘起 していることが挙げられる。一方, 分子間水素結合は分子 同士を強固に結合し, (高分子のように) 2 次元あるいは3

日本結晶学会誌 第 44 巻第 1 号 (2002)
次元のネットワークを形成し結晶を安定化させている.さ らに, 強固な水素結合は溶媒に対する顔料の溶解度を下げ る効果も果たしている.

\section{8. 結晶多形の応用と分子間力の評価方法}

結晶多形の応用に関するトピックスとして, DTPPの近 赤外吸収と光電導現象を利用したレーザープリンター2) やDTPPならびにペリレン顔料の結晶相転移を使った光 ディスクの例がある.31.13) また, 原子レベルにおける分子 間力の評価方法としてエネルギー分割法が有効であるこ とがわかってきた. DTPP,14) チオインジゴ,15) テトラチオ ベンゾキノン 16) マグネシウムフタロシアニン17)などで 検討されている. 適宜, 文献をご参照戴きたい.

\section{9. おわりに}

有機顔料は溶媒に極めて難溶で単結晶の育成には困難 が伴う。この意味で結晶構造予測の分野が今後ますます発 展し,さらには構造と物性の相関関係の予測へと結実する ことを切に願っている.

\section{文 献}

1) M. Herbst and K. Hunger: Industrial Organic Pigments, VCH (1993).

2) J. Mizuguchi and A. C. Rochat: J. Imag. Sci. 32, 135 (1988).

3) J. Mizuguchi, G. Giller and E. Baeriswyl: J. Appl. Phys. 75, 514 (1994).

4) J. Mizuguchi, A. C. Rochat and G. Rihs: Ber. Bunsenges. Phys. Chem. 97, 607 (1992).

5) J. Mizuguchi, G. Rihs and H. Karfunkel: J. Phys. Chem. 99, 16217 (1995).

6) M. Kasha: Spectroscopy of the Excited State, Ed. by B. Di Bartolo, Prenum Press new York, 337 (1976).

7) D. P. Craig and S. H. Walmsley: Excitons in Molecular Crystals, W. A. Benjamin, Inc., New York (1968).

8) J. Mizuguchi, A. C. Rochat and G. Rihs: Acta Cryst. C46, 1899 (1990). 9) J. Mizuguchi, M. Arita and G. Rihs: Acta Cryst. C47, 1952 (1991).

10) T. Kobayashi: J-Aggregates; World Scientific Publishing Co. Pte. Ltd. (1996).

11) 水口 仁: 日本結晶学丟誌 43, 234 (2001).

12) J. Mizuguchi：電子写真学会誌 37, 58 (1998).

13) J. Mizuguchi: J. Appl. Phys. 84, 4479 (1998).

14) J. Mizuguchi：電子写真学会誌 37, 67 (1998).

15）望月美里, 千住孝俊, 水口 位: 日本画像学会誌 39, 421 (2000).

16) S. Matumoto and J. Mizuguchi: Bull. Chem. Soc. Jpn. 74, 471 (2001).

17) J. Mizuguchi: J. Phys. Chem. A 105, 10719 (2001).

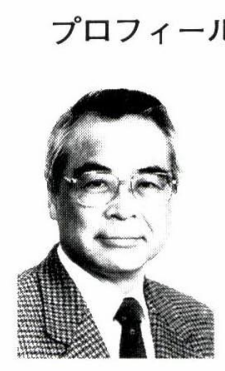

水口 位 Jin MIZUGUCHI 横浜国立大学大学院工学研究院

Graduate School of Engineering, Yokohama National University

于 240-8501 横浜市保土ヶ谷区常盤台 79-5

Tel. \& Fax. 045-339-3369

E-mail: mizu-j@ynu.ac.jp

最終学歴: 上智大学理丁学部化学科

専門分野：分子性結晶の電子構造

現在のテーマ: 構造と物性の相関

趣味：クラシックカメラ 